\title{
Biosorption of hexavalent chromium by Aspergillus fumigatus S101 isolated from a coal mining environment
}

\author{
Satarupa Dey ${ }^{1 *}$, Swagata Bhattacharya ${ }^{2}$, Rajyasri Ghosh², Shampa Bhattacharyya ${ }^{2}$ \\ ${ }^{1}$ Agricultural and Ecological Research unit, Indian Statistical Institute, 203 Barrackpore Trunk Road, Kolkata 7000108, India \\ ${ }^{2}$ Mycology and plant pathology laboratory, Department of Botany, Scottish Church College, 1 and 3 Urquhart Square, Kolkata 700006, \\ India \\ *Corresponding author, E-mail: dey1919@gmail.com
}

\begin{abstract}
In this study attempts were made to isolate a Cr-binding fungal population from coal mine soils of Jharkhand, India. A total of 15 fungal isolates belonging to the genera Aspergillus, Penicillium and Fusarium were obtained from the soils. Among them, Aspergillus fumigatus S101 was found to tolerate up to $5 \mathrm{mM} \mathrm{Cr}(\mathrm{VI})$ and showed maximum metal uptake capacity of $1.868 \mathrm{mM} \mathrm{g}^{-1}$ biomass in presence of $0.5 \mathrm{mM} \mathrm{Cr}(\mathrm{VI})$ within $48 \mathrm{~h}$. The sorption capacity was standardized following Langmuir and Freundlich absorption isotherm models that followed pseudo-second-order kinetics. The biosorption ability of A. fumigatus $\mathrm{S} 101$ was maximum at $\mathrm{pH} 5$ and at $30{ }^{\circ} \mathrm{C}$. There was a decrease in metal uptake capacity with increase in biomass, but with the increase in $\mathrm{Cr}(\mathrm{VI})$ concentration metal uptake capacity increased. The sorption capacity increased in presence of metal ions such as $\mathrm{Fe}(\mathrm{III})$ and $\mathrm{Cu}$ (II) showing complete removal of $0.5 \mathrm{mM}$ $\mathrm{Cr}(\mathrm{VI})$ within $36 \mathrm{~h}$. Treatment of biomass with Tween 80 resulted in maximum sorption accounting for $100 \%$ removal of $0.5 \mathrm{mM} \mathrm{Cr}(\mathrm{VI})$ in $24 \mathrm{~h}$. The results suggested that the mycelial mass of A. fumigatus (S101) is capable of efficient removal of $\mathrm{Cr}(\mathrm{VI})$ from aqueous solution.
\end{abstract}

Key words: absorption isotherm models, Aspergillus fumigatus, coal mine soils, $\mathrm{Cr}(\mathrm{VI})$ biosorption.

Abbreviations: $\mathrm{Cr}(\mathrm{VI})$, hexavalent chromium; Cr(III), trivalent chromium; EDX, energy dispersive X ray analysis; FTIR, Fourier Transform Infrared; MIC, minimal inhibitory concentration; PDA, potato dextrose agar; SEM, scanning electron microscopy.

\section{Introduction}

The mining industry is mostly associated with high degree of overexploitation of natural resources for extraction of minerals, which leads to immense environmental pollution and major destruction of habitats. Such overexploitation and physical weathering often results in the release of different types of heavy metals in the environment (Mileusnic et al. 2014).

Waste water discharged from coal mines is usually reported to contain several heavy metals including $\mathrm{Cr}$ (Masto et al. 2015), which mainly exists in two stable valance states, the trivalent and the hexavalent. The main difference between these two valence states is that $\mathrm{Cr}$ (III) is less bioavailable in the natural environment and therefore less toxic (Rai et al. 1987), whereas Cr(VI) is highly soluble, can permeate cell membrane and is toxic, carcinogenic and mutagenic (Bagchi et al. 2002). Cr(VI) has also been reported to cause oxidative stress in cells by generating reactive oxygen species and subsequently leading to DNA damage and altered gene expression. Therefore, removal of $\mathrm{Cr}(\mathrm{VI})$ is essential for mitigation of such contaminated mining areas.

Different physicochemical methods have been applied for treatment of metal contaminated wastes, but most of these methods are not environment friendly and removal of toxic metals by biological methods such as biosorption, bioreduction and biotransformation has been long preferred as an environment friendly alternative. Several microorganisms, both in dead and living conditions, have been reported to have metal binding and removal ability which can be effectively utilized for mitigation of metal contaminated wastes (Dey, Paul 2010; Jia et al. 2014; Mala et al. 2006). Isolates like Pseudomonas aeruginosa (Chatterjee et al.2011), Aspergillus niger and Micrococcus sp. (Congeevaram et al. 2007) obtained from tannery effluent and electroplating industry have been previously reported to be effective in biosorption of $\mathrm{Cr}(\mathrm{VI})$. A high proportion of cell wall material in fungal biomass has been reported to facilitate the biosorption procedure in both batch as well as continuous cultures. Different species of Aspergillus have been reported to be very efficient in biosorption and bioaccumulation of $\mathrm{Cr}(\mathrm{VI})$ by different groups of authors (Srivastava, Thakur 2006; Ghosh et al. 2015).

In the present study, soil samples were collected from both abandoned and active coal mines of Jharkhand, India, an area that is rich in different mineral deposits. Mining in this area started as early as 1774 and recent studies 
show that continuous mining has lead to destruction of the ecological balance and have generated huge amount metal containing mine waste (Manna, Maiti 2017), which has direct impact on the microflora of the region. Previous studies have shown the presence of $\mathrm{Cr}(\mathrm{VI})$ in the coal mining areas in the range of 1.09 to $12.1 \mu \mathrm{g} \mathrm{L}{ }^{-1}$ (Mahato et al. 2014), which in some cases exceeds the maximum allowable concentration for Cr (Das, Chakrapani 2011), showing a medium level of heavy metal pollution index. In this study $\mathrm{Cr}(\mathrm{VI})$ resistant fungal strains were isolated from the coal mine soils and identified. The ability of these fungal strain in $\mathrm{Cr}(\mathrm{VI})$ biosorption ability were quantified in details with the intention of potential application of fungal biomass for removal of $\mathrm{Cr}(\mathrm{VI})$ from contaminated water.

\section{Materials and methods}

\section{Collection of samples}

A total of eight mine soil samples were collected, including two each from Giddi, Religara, Balkundra and Sangam open cast mines of North Karanpura coal fields (23.61 to $23.71^{\circ}$ $\mathrm{N}, 85.27$ to $85.46^{\circ} \mathrm{E}$ ) of Jharkhand, India during January in 2017. The open cast mines of the Sangam area was abandoned in 1990, while the others were operating mines. Soils were collected from the subsurface zone in ziplock pouches and stored at $4{ }^{\circ} \mathrm{C}$ for further microbiological analysis.

\section{Isolation of fungal strains}

Serially diluted soil samples were plated on potato dextrose agar (PDA) plates, amended with streptomycin (Himedia) and incubated for 4 to 6 days at $30 \pm 2{ }^{\circ} \mathrm{C}$. Morphologically distinct fungal strains appeared on the plate and were isolated in pure form. The pure cultures were maintained on slopes of PDA at $4{ }^{\circ} \mathrm{C}$ and subcultured at regular intervals.

The micromorphological characteristics of the fungal isolates were studied in detail to confirm their generic identity following the Manual of Soil Fungi by Gilman (1957) and Manual of Penicillia (Raper, Thom 1984).

\section{Evaluation of $\mathrm{Cr}(\mathrm{VI})$ resistance}

The chromium tolerance of these fungal isolates was evaluated following the agar dilution method (Cervantes, Ohtake 1988) in which they were allowed to grow in PDA plates amended with 1.0 to $5.0 \mathrm{mM} \mathrm{Cr}(\mathrm{VI})$ at $30 \pm 2{ }^{\circ} \mathrm{C}$ and the minimum concentration of metal that inhibited growth of the fungal isolate was considered as the minimal inhibitory concentration (MIC) for that particular isolate.

\section{Preparation of fungal biomass}

To produce the biomass necessary for biosorption experiment, potato dextrose broth medium $(50 \mathrm{~mL}$ per 250 $\mathrm{mL}$ Erlenmeyer flask) was inoculated with a homogeneous spore suspension prepared from 4-day-old slant cultures of selected isolate using sterile Tween $80(0.1 \% \mathrm{w} / \mathrm{v})$ solution. The biomass was harvested by centrifugation at $6000 \times \mathrm{g}$ for 10 min using a Remi R24 centrifuge and washed with distilled water. This was followed by drying of biomass at $80^{\circ} \mathrm{C}$ for $96 \mathrm{~h}$. The biomass was then powdered in a mortar with pestle, sieved through $0.1 \mathrm{~mm}$ mesh and stored in desiccators at room temperature for future use.

\section{Biosorption studies}

$\mathrm{Cr}(\mathrm{VI})$ biosorption was studied using an initial $\mathrm{Cr}(\mathrm{VI})$ concentration (as $\mathrm{K}_{2} \mathrm{CrO}_{4}$ ) of $0.5 \mathrm{mM}$ in double distilled water $(25 \mathrm{~mL})$ containing a biomass level of $2 \%$. The flasks were incubated at $30{ }^{\circ} \mathrm{C}$ for $48 \mathrm{~h}$ in a rotary shaker $(120$ $\mathrm{rpm})$ and samples $(1 \mathrm{~mL})$ were withdrawn at regular intervals, centrifuged (10 $000 \times \mathrm{g}$ for $10 \mathrm{~min})$ and filtered through Whatman No. 42 filter paper. The residual Cr(VI) were estimated by measuring the decrease in hexavalent chromium in the supernatant following the standard 1, 5-diphenylcarbazide method (Park et al. 2000). The Cr(VI) biosorption was represented as $\mathrm{Cr}(\mathrm{VI})$ biosorption in $\mathrm{mM}$ per $g$ of biomass. All of the experiments were done in triplicate.

\section{Estimation of $\mathrm{Cr}(\mathrm{VI})$ biosorption ability}

The total Cr(VI) biosorption capacity, designated as qt, was estimated following the standard mass balance equation

$$
q_{t}=\left(C_{o}-C_{t}\right) V / W
$$

where $C_{o}(\mathrm{mM})$ and $C_{t}(\mathrm{mM})$ designates the initial and the residual $\mathrm{Cr}(\mathrm{VI})$ concentration at incubation times $t_{0}=0 \mathrm{~h}$ and $t=\mathrm{t} \mathrm{h}$, respectively, $\mathrm{V}$ designates the solution volume in $\mathrm{L}$ and $\mathrm{W}$ represents the biomass in $\mathrm{g}$ and the biosorption capacity was expressed as $\mathrm{Cr}(\mathrm{VI})$ biosorption in $\mathrm{mM}$ per $\mathrm{g}$ biomass.

\section{Scanning electron microscopic studies}

The surface morphology of the biosorbent was studied by scanning electron microscopy (SEM, Zeiss EVO 18). For SEM studies, A. fumigatus S101 biomass samples before and after biosorption were dehydrated with 50, 70, 90 and $100 \%$ ethanol, mounted on an aluminium stab and coated with a 10-nm thick platinum coating in a Quorum Q150 TES sputter coater for 10 min under vacuum.

\section{Fourier Transform Infrared studies}

The chemical nature of the biosorbent surface, before and after adsorption of $\mathrm{Cr}(\mathrm{VI})$ was examined by a Fourier Transform Infrared Spectrometer (Perkin-Elmer). Prior to FTIR analysis, $\mathrm{KBr}$ pellets were prepared with the biomass and analyzed for any changes of the chemical nature of the biosorption surface.

\section{Kinetic studies}

To determine the mechanism of adsorption, the adsorption rates were fitted into pseudo first order and pseudo second order kinetic models as proposed by Lagergren (1898) and 
Ho and McKay (1999) respectively.

The pseudo-first-order kinetic model for adsorption of solute from a liquid solution is described by the following equation:

$$
\log \left(q_{e q}-q_{t}\right)=\log q_{e q}-k_{1}(t / 2.303)
$$

where $q_{t}$ is the amount of $\mathrm{Cr}(\mathrm{VI})$ adsorbed at time $t[\mathrm{mM}$ $\mathrm{Cr}(\mathrm{VI})$ per g biomass]; $q_{e q}$ is the amount of $\mathrm{Cr}(\mathrm{VI})$ adsorbed at equilibrium [mM $\mathrm{Cr}(\mathrm{VI})$ per $\mathrm{g}$ biomass]; and $k_{1}$ is the equilibrium rate constant for pseudo-first-order reaction $\left(\mathrm{min}^{-1}\right)$; and $t=$ time $(\mathrm{min})$.

The adsorption kinetics may also be described by the pseudo-second-order kinetic model expressed by the equation

$$
t / q_{t}=1 / k_{2}\left(q_{e q}\right) 2+1 / q_{e q}
$$

where the intercepts and slopes of $t / q_{t}$ versus $t$ were used to determine the pseudo-second order rate constant $k_{2}$ and equilibrium adsorption density $q_{e q}$, respectively.

\section{Statistical analyis}

All experiments were performed in triplicate and results represent mean \pm standard error.

\section{Results}

A total of 15 fungal isolates were obtained from the eight coal mine soil samples on PDA plates supplemented with streptomycin. However, fungal isolate was not found in sample S3, which was collected from the active opencast mining site of Giddi colliery. Six different fungal isolates were obtained from sample S1 collected from Religara open cast mines. All of the 15 fungal isolates were identified (Table 1) and screened for their tolerance to $\mathrm{Cr}(\mathrm{VI})$. A total of eight fungal isolates were capable of growing even in the presence of $5.0 \mathrm{mM} \mathrm{Cr}(\mathrm{VI})$ and were selected as potent $\mathrm{Cr}(\mathrm{VI})$ resistant strains (Table 1). The fungal isolates were identified following the Manual of Soil Fungi by Gilman (1957) and Manual of Penicillia (Raper, Thom 1984), and was found to belong mostly to the genera Aspergillus, Fusarium and Penicillium (Table 1). The species of
Table 1. Identification and minimum inhibitory concentration of the $\mathrm{Cr}(\mathrm{VI})$ resistant fungal isolates obtained from coal mine soils of Jharkhand, India. ${ }^{*}$ Identification were done according to the Manual of Soil Fungi by Gilman (1957) and Manual of Penicillia (Raper, Thom 1984). ${ }^{* *}$ MIC (minimum inhibitory concentration) was determined following agar dilution method using $\mathrm{Cr}(\mathrm{VI})$ concentration of 1 to $5 \mathrm{mM}$

\begin{tabular}{lllc}
$\begin{array}{l}\text { Sample } \\
\text { No. }\end{array}$ & $\begin{array}{l}\text { Isolate } \\
\text { No. }\end{array}$ & Identified isolates & MIC $(\mathbf{m M})^{* *}$ \\
S1 & S101 & Aspergillus fumigatus & 5 \\
& S102 & Aspergillus niger & 3 \\
& S103 & Aspergillus niger & - \\
& S104 & Aspergillus niger & - \\
& S105 & Fusarium oxysporum & 5 \\
\hline & S106 & Penicillium sp. & - \\
S2 & S201 & Aspergillus terreus & 5 \\
\hline S4 & S401 & Penicillium sp. & 5 \\
\hline & S402 & Penicillium sp. & - \\
\hline S5 & S501 & Aspergillus candidus & 5 \\
\hline & S502 & Aspergillus koningi & - \\
S6 & S601 & Penicillium sp. & 5 \\
S7 & S701 & Penicillium sp. & 5 \\
S8 & S801 & Penicillium sp. & - \\
\end{tabular}

Aspergillus were Aspergillus fumigatus (S101), Aspergillus niger (S102, S103 and S104), Aspergillus terreus (S 201), Aspergillus candidus (S 501) and Aspergillus koningi (S502). Isolates S106, S401, S402, S601, S701 and S801 belonged to genera Penicillium.

All these eight fungal isolates were further selected and screened for their $\mathrm{Cr}(\mathrm{VI})$ biosorption ability in aqueous solution using dried fungal biomass. The results clearly indicated that the $\mathrm{Cr}(\mathrm{VI})$ binding capacity of the fungal biomass varied to different degrees (Table 2). All isolates showed high metal loading potential ranging from $1.524 \pm$ 0.36 to $1.868 \pm 0.91 \mathrm{mM} \mathrm{Cr}(\mathrm{VI})$ per g of biomass. However, after incubating for $48 \mathrm{~h}$, maximum $\mathrm{Cr}(\mathrm{VI})$ biosorption was achieved with A. fumigatus S101 biomass, which was able

Table 2. Screening of $\mathrm{Cr}(\mathrm{VI})$-resistant fungi for biosorption of $\mathrm{Cr}(\mathrm{VI})$. Initial $\mathrm{Cr}(\mathrm{VI})$ concentration $\left(\mathrm{as}_{2} \mathrm{CrO}_{4}\right)$ of $0.5 \mathrm{mM}$ and a biomass level of $2 \%$, incubation: $30{ }^{\circ} \mathrm{C}$ at $120 \mathrm{rpm}$. All experiments were performed in triplicate and results represent mean \pm standard error

\begin{tabular}{lcccc} 
Fungal isolate & \multicolumn{4}{c}{$\begin{array}{c}\text { Cr(VI) biosorption } \text { [mM Cr(VI) per g biomass] } \\
\text { Time of incubation (h) }\end{array}$} \\
\cline { 2 - 5 } & $\mathbf{1 2}$ & $\mathbf{2 4}$ & $\mathbf{3 6}$ & $\mathbf{4 8}$ \\
Aspergillus fumigatus S101 & $1.68 \pm 0.10$ & $1.74 \pm 0.30$ & $1.84 \pm 0.96$ & $1.87 \pm 0.91$ \\
Aspergillus niger S102 & $1.66 \pm 0.12$ & $1.70 \pm 0.28$ & $1.74 \pm 0.56$ & $1.78 \pm 0.13$ \\
Fusarium oxysporum S105 & $1.39 \pm 0.07$ & $1.48 \pm 0.58$ & $1.54 \pm 0.24$ & $1.52 \pm 0.36$ \\
Aspergillus terreus S201 & $1.68 \pm 0.10$ & $1.75 \pm 0.62$ & $1.76 \pm 0.21$ & $1.81 \pm 0.11$ \\
Penicillium sp. S401 & $1.64 \pm 0.12$ & $1.66 \pm 0.11$ & $1.72 \pm 0.34$ & $1.71 \pm 0.32$ \\
Aspergillus sp. S404 & $1.64 \pm 0.04$ & $1.68 \pm 0.56$ & $1.72 \pm 0.16$ & $1.73 \pm 0.19$ \\
Aspergillus candidus S501 & $1.42 \pm 0.07$ & $1.50 \pm 0.92$ & $1.53 \pm 0.42$ & $1.57 \pm 0.31$ \\
Penicillium sp. S701 & $1.48 \pm 0.05$ & $1.60 \pm 0.56$ & $1.75 \pm 0.52$ & $1.76 \pm 0.41$
\end{tabular}



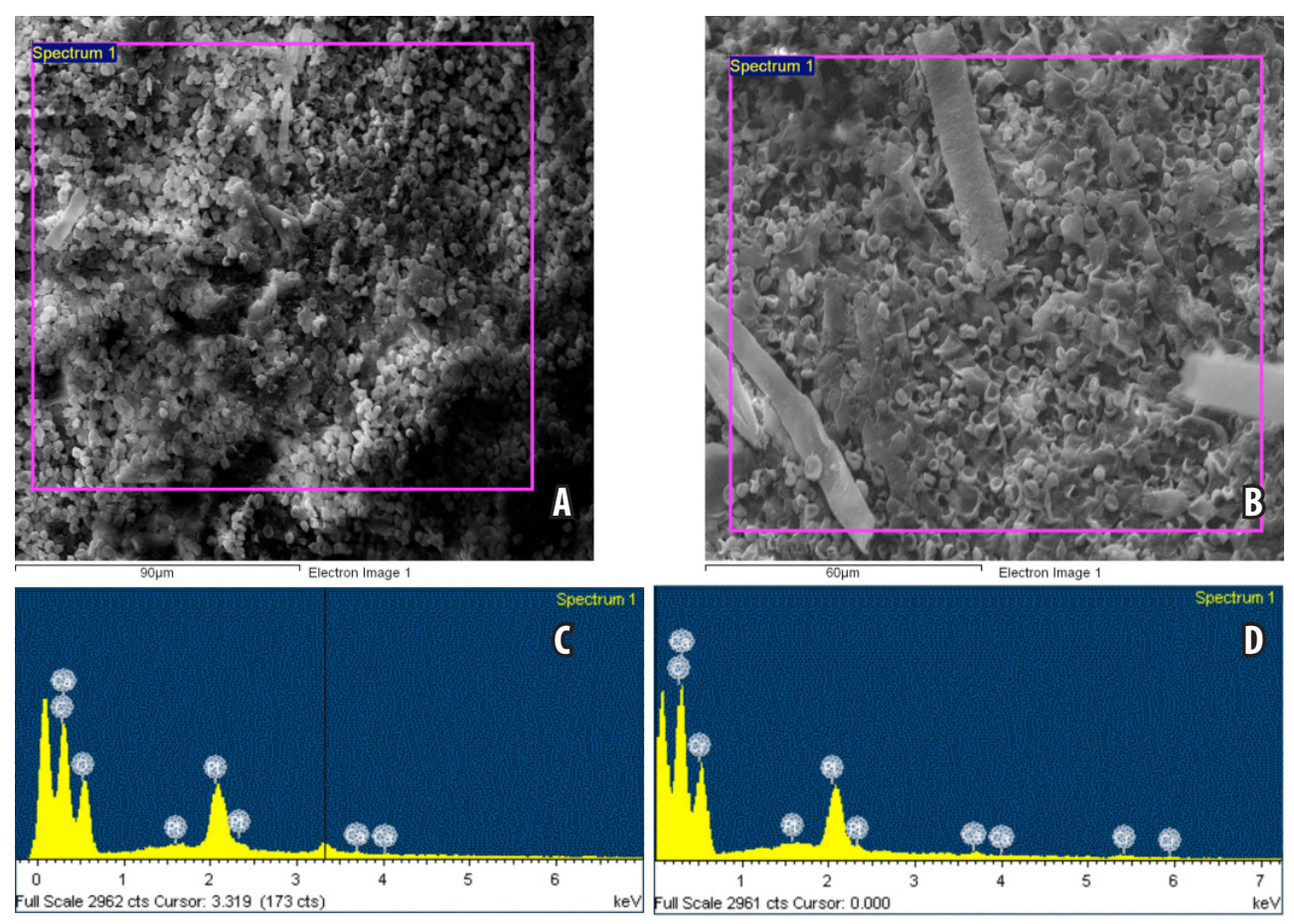

Fig. 1. Scanning electron microscopic images of biomass of Aspergillus fumigatus S101 before (A) and after (B) Cr(VI) biosorption. EDX analysis of the same samples before (C) and after Cr(VI) biosorption (D).

to remove nearly $93 \%$ of initial $0.5 \mathrm{mM} \mathrm{Cr}(\mathrm{VI})$, showing a metal loading capacity of $1.868 \pm 0.91 \mathrm{mM} \mathrm{Cr}(\mathrm{VI})$ per $\mathrm{g}$ of biomass. A. fumigatus $\mathrm{S} 101$ was, therefore, selected as the best biosorbent and its optimal conditions for $\mathrm{Cr}(\mathrm{VI})$ biosorption were evaluated.

The surface morphology of dried and powdered fungal biomass was studied under scanning electron microscopic studies both before and after $\mathrm{Cr}(\mathrm{VI})$ biosorption to observe changes. SEM images showed a heterogenous nature of the mycelia (Fig. 1A, B), which can serve as an active site for metal binding. Significant morphological changes were not visible in the SEM image after treatment with $\mathrm{Cr}(\mathrm{VI})$. The fungal hyphae appeared to be cylindrical, septate, and branched in nature. The EDX analysis of the biomass after treatment with $\mathrm{Cr}(\mathrm{VI})$ confirmed the presence of chromium within the cell mass (Fig. 1 D) suggesting possible attachment of metal on the active sites present in the biomass.

FTIR spectra analysis of the dried fungal biomass before and after $\mathrm{Cr}(\mathrm{VI})$ biosorption was done to obtain information about the nature of surface functional groups. A variety of stretching frequency was visible in the spectrum indicating its complex nature (Fig. 2A, B) and distinct change in the spectra after $\mathrm{Cr}(\mathrm{VI})$ biosorption was noticed mainly in the range of 1642 to $1038 \mathrm{~cm}^{-1}$. The bands formed at $3388,1642,1399 \mathrm{~cm}^{-1}$ for unloaded biomass (Fig. 2A) shifted to 3332,2851 and $1644 \mathrm{~cm}^{-1}$, however, bands at $618 \mathrm{~cm}^{-1}$ remained the same.

As the initial $\mathrm{Cr}(\mathrm{VI})$ concentration in the metal solution increased from 0.25 to $4.0 \mathrm{mM}$ there was a sharp increase in the metal loading capacity by A. fumigatus S101 biomass. The metal loading capacity of the biomass increased nearly 10 times from 0.902 to $9.28 \mathrm{mM} \mathrm{Cr}(\mathrm{VI})$ per $\mathrm{g}$ biomass (Fig. 3). However, there was no noticeable increase in metal loading capacity when the $\mathrm{Cr}(\mathrm{VI})$ concentration was increased to $8 \mathrm{mM}$, as the maximum metal loading capacity was found to be around $9.3 \mathrm{mM} \mathrm{Cr}(\mathrm{VI})$ per $\mathrm{g}$ biomass.
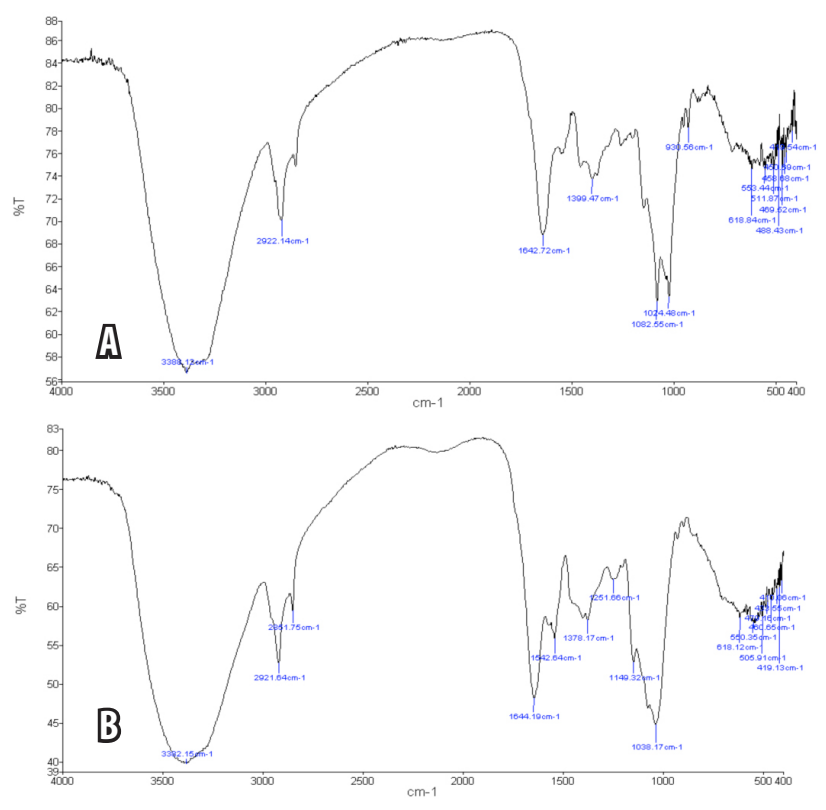

Fig. 2. FTIR analysis of the biomass of Aspergillus fumigatus S101 before (A) and after (B) $\mathrm{Cr}(\mathrm{VI})$ biosorption. 


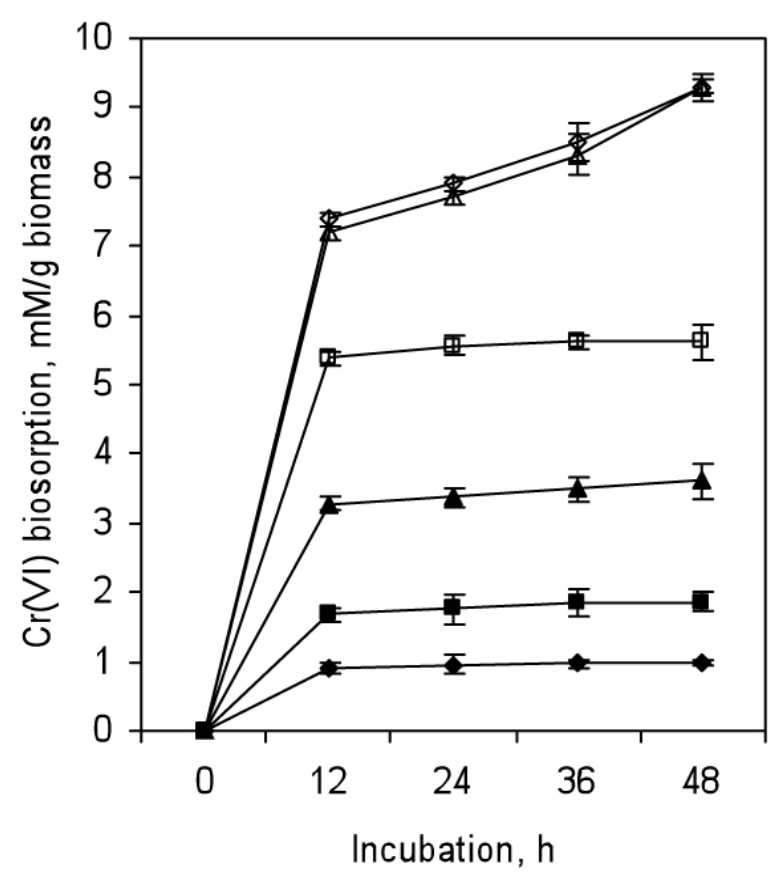

Fig. 3. Effect of sorbent concentration on $\mathrm{Cr}(\mathrm{VI})$ biosorption by biomass of Aspergillus fumigatus S101 [- - 0.25, - - $-0.5,-\mathbf{\Delta}$ - 1.0, $-\square-2.0,-\Delta-4.0$ and $-\diamond-8.0 \mathrm{mM} \mathrm{Cr}(\mathrm{VI})]$. Biosorption studies were carried out in batch mode with $2 \%$ biomass, incubation $30^{\circ} \mathrm{C}$ at $120 \mathrm{rpm}$.

The standard adsorption isotherms such as Langmuir and Freundlich isotherms were used to quantify the biosorption equilibrium following the standard formulae.

Langmuir model: $\mathrm{Q} e=(a) \times(b) \times C e / 1+(b) \times C e$ and the Freundlich model: $\mathrm{Qe}=K(\mathrm{Ce})^{1 / \mathrm{n}}$,

where $Q e$ is the amount of metal ion biosorbed at equilibrium per unit weight of biomass, whereas $\mathrm{Ce}$ represents the metal ion concentration at equilibrium. Langmuir constants are represented as "a" and "b", while "K" and " $n$ " represents the Freundlich model constants. The linearised Langmuir and Freundlich adsorption isotherms for $\mathrm{Cr}(\mathrm{VI})$ biosorption by A. fumigatus S101 are presented in Fig. $4 \mathrm{~A}$ and $\mathrm{B}$ respectively. The adsorption constants along with correlation coefficients were calculated (Table 3) from the isotherms.

The constants for Langmuir model were found to be: $(a)$ and $(b)$ as 6.147 and 0.0811 respectively, while those for Freundlich isotherms were $(K)$ as 2.3 and $(n)$ as 1.4.

The process of biosorption by A. fumigatus S101 biomass could be explained with the help of kinetic models. The pseudo-second order kinetic model was tested
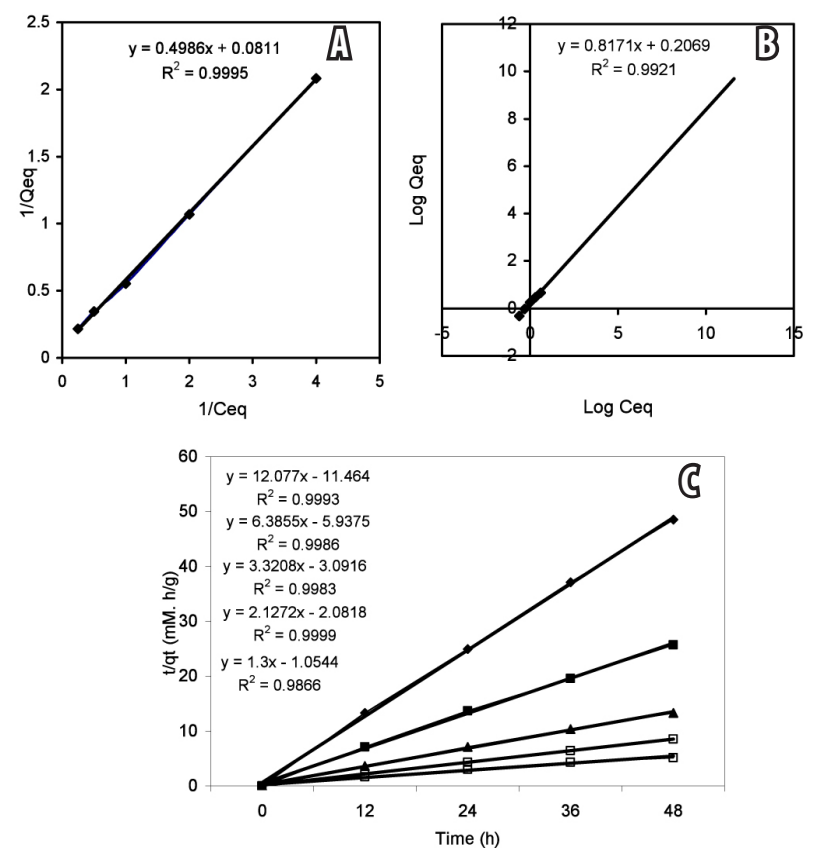

Fig. 4. The linearised Langmuir (A) and Freundlich (B) adsorption isotherms of $\mathrm{Cr}(\mathrm{VI})$ by Aspergillus fumigatus S101 biomass. (C), pseudo-second order plot (b) for the biosorption of $\mathrm{Cr}(\mathrm{VI})$ by Aspergillus fumigatus S101 biomass.

with the experimental data to understand the kinetics of $\mathrm{Cr}$ (VI) biosorption. The current experiment (Fig. 4C) was in good agreement with the pseudo-second-order kinetic model over all the concentrations studied. The regression coefficient $\left(R^{2}\right)$ was more close to unity, which supported the validity of a pseudo-second order kinetic model for the $\mathrm{Cr}$ (VI) biosorption by A. fumigatus S101 biomass.

The metal uptake capacity by A. fumigatus S101 biomass is strongly influenced by the $\mathrm{pH}$ and temperature of the solution. The optimum $\mathrm{pH}$ and temperature was found to be 5.0 (Fig. 5A) and $30{ }^{\circ} \mathrm{C}$ (Fig. 5B) showing a metal loading capacity of 2.0 and $1.924 \mathrm{mM} \mathrm{Cr}(\mathrm{VI})$ per g biomass respectively.

$\mathrm{Cr}$ (VI) biosorption capacity of the fungal biomass was influenced by the initial biomass concentration. The maximum $\mathrm{Cr}(\mathrm{VI})$ adsorption was achieved when the biomass concentration was kept at the level of $1 \%$ where the metal loading capacity was nearly $1.948 \mathrm{mM} \mathrm{Cr}(\mathrm{VI})$ per $\mathrm{g}$ biomass. However, the metal loading capacity of the dried biomass declined with increase in biomass concentration (Fig. 6).

Table 3. Equilibrium isotherms for $\mathrm{Cr}(\mathrm{VI})$ biosorption by Aspergillus fumigatus S101 biomass. Qe, $\mathrm{Cr}(\mathrm{VI})$ biosorbed mM Cr(VI) per g biomass; $\mathrm{Ce}$, residual chromium at equilibrium

$\begin{array}{lccc}\text { Model } & \text { Equation } & \text { Isotherm constant } & \text { Corelation coefficient, } \mathbf{R}^{2} \\ \text { Langmuir } & Q e=0.4986 \mathrm{Ce} / 1+0.0811 \mathrm{Ce} & a=6.147, b=0.0811 & 0.995 \\ \text { Freundlich } & \mathrm{Q} e=K(\mathrm{Ce})^{1 / \mathrm{n}} & K=2.316, n=1.4 & 0.992\end{array}$



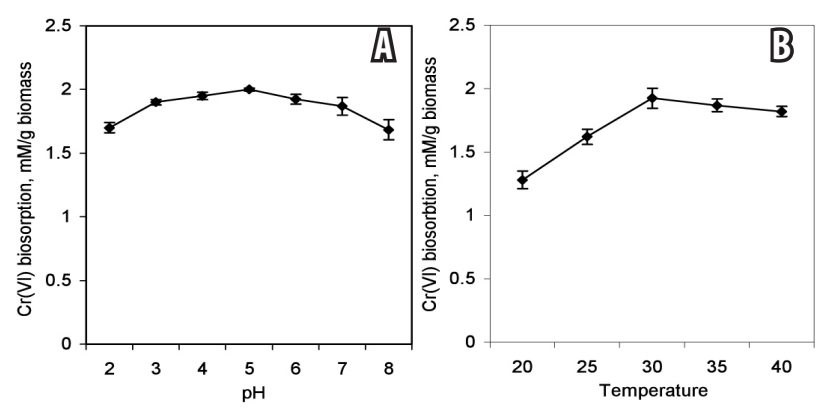

Fig. 5. Effect of $\mathrm{pH}(\mathrm{A})$ and temperature (B) on $\mathrm{Cr}(\mathrm{VI})$ biosorption by Aspergillus fumigatus S101 biomass. Biosorption studies were carried out in batch mode with $2 \%$ biomass and $0.5 \mathrm{mM} \mathrm{Cr}(\mathrm{VI})$ concentration at $120 \mathrm{rpm}$ for $48 \mathrm{~h}$.

Additional metal cations at equimolar concentration were found to affect the metal loading capacity of the dried biomass of A. fumigatus S101. Several metal ions including $\mathrm{Ni}$ (II), $\mathrm{Zn}$ (II), $\mathrm{Co}$ (II), $\mathrm{Pb}$ (II), $\mathrm{Fe}$ (II) and $\mathrm{Cu}$ (II) (as chloride salt) were tested. The results (Table 4) clearly indicated that $\mathrm{Ni}$ (II) was most inhibitory, showing $\mathrm{Cr}(\mathrm{VI})$ biosorption capacity of $1.280 \pm 0.25 \mathrm{mM} \mathrm{Cr}(\mathrm{VI})$ per g biomass, accounting for about $68.2 \%$ of the control. Presence of $\mathrm{Fe}$ (III) ions and $\mathrm{Cu}$ (II) was found to promote uptake of $\mathrm{Cr}(\mathrm{VI})$ ions by $A$. fumigatus $\mathrm{S} 101$ biomass showing a metal loading capacity of nearly $2.0 \pm 0.17 \mathrm{mM} \mathrm{Cr}(\mathrm{VI})$ per $\mathrm{g}$ biomass.

Pretreatment of A. fumigatus S101 biomass with various chemical and physical agents have a profound effect on $\mathrm{Cr}(\mathrm{VI})$ biosorption and the metal loading capacity. It was found that autoclaving of the sample for $15 \mathrm{~min}$ in 103 $\mathrm{kPa}$ as well as treatment with $0.5 \mathrm{M}$ sulphuric acid and $\mathrm{NaOH}$ was found to reduce the metal loading capacity of the biomass (Table 4). However, pretreatment with $0.5 \mathrm{M}$ Tween 80 was found to promote the $\mathrm{Cr}(\mathrm{VI})$ biosorption rate, up to maximum rate of $2 \mathrm{mM} \mathrm{Cr}(\mathrm{VI})$ per g biomass after $48 \mathrm{~h}$ of incubation.

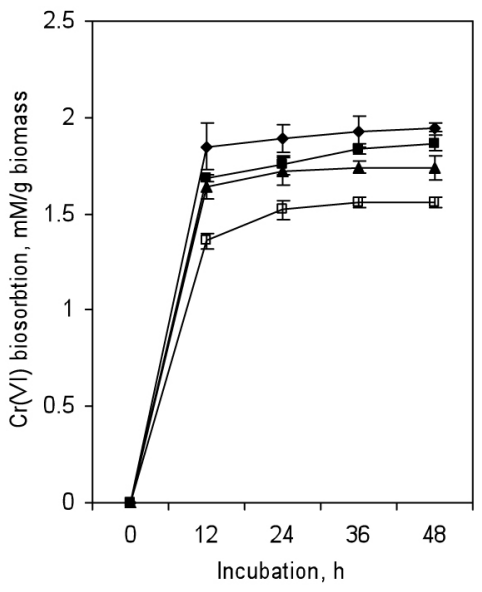

Fig. 6. Effect of initial biomass concentration on $\mathrm{Cr}(\mathrm{VI})$ biosorption by biomass of Aspergillus fumigatus S101. [- $\$$,

- 2, - $\mathbf{\Delta}-3,-\square-4 \%$ biomass]. Biosorption studies were carried out in batch mode after $48 \mathrm{~h}$ incubation using an initial $\mathrm{Cr}(\mathrm{VI})$ concentration of $0.5 \mathrm{mM}$ at $30^{\circ} \mathrm{C}$.

\section{Discussion}

The soil samples in and around coal mining areas have been reported to contain several heavy metals such as chromium, lead, zinc and nickel (Khan et al. 2017; Manna, Maiti 2017). The indigenous microbiota obtained from the soil of such mining areas was found to tolerate different types of heavy metals. Similar results were also made by Upadhyay et al. (2017), where they reported presence of metal tolerant microbes from degraded soils of coal mining areas of Uttar Pradesh.

A total of 15 fungal isolates were obtained from these soil samples and majority of these isolates taxonomically belonged to genus Aspergillus, Penicillium and Fusarium sp. (Table 1). Similar observations were also made by Ahmad et al. (2005) and Zafar et al. (2007) who reported the presence of Aspergillus sp. as the most common genus in heavy metal contaminated soils.

Table 4. Effect of additional metal cations and pretreatment on $\mathrm{Cr}(\mathrm{VI})$ biosorption by biomass of Aspergillus fumigatus S101. ${ }^{\star}$ Both the initial $\mathrm{Cr}(\mathrm{VI})$ and additional metal concentration was kept at $0.5 \mathrm{mM}$. Incubation period $48 \mathrm{~h}$. Results represent mean of triplicate experiments \pm standard error

\begin{tabular}{lcc} 
Treatment & $\begin{array}{c}\text { Cr(VI) biosorption } \\
{[\mathbf{m M ~ C r}(\mathbf{V I}) \text { per g biomass }]}\end{array}$ & Biosorption (\% of control) \\
\hline Control $[\mathrm{Cr}(\mathrm{VI})]$ & $1.87 \pm 0.91$ & 100.00 \\
$\mathrm{Cr}(\mathrm{VI})+\mathrm{Ni}(\mathrm{II})$ & $1.28 \pm 0.25$ & 68.20 \\
$\mathrm{Cr}(\mathrm{VI})+\mathrm{Zn}(\mathrm{II})$ & $1.62 \pm 0.34$ & 86.18 \\
$\mathrm{Cr}(\mathrm{VI})+\mathrm{Pb}(\mathrm{II})$ & $1.37 \pm 0.91$ & 73.09 \\
$\mathrm{Cr}(\mathrm{VI})+\mathrm{Fe}(\mathrm{III})$ & $2.00 \pm 0.17$ & 106.40 \\
$\mathrm{Cr}(\mathrm{VI})+\mathrm{Cu}(\mathrm{II})$ & $2.00 \pm 0.10$ & 106.40 \\
\hline Autoclaved & $1.56 \pm 0.24$ & 83.51 \\
\hline $0.5 \mathrm{M} \mathrm{Tween} 80$ & $2.00 \pm 0.10$ & 110.20 \\
$0.5 \mathrm{M} \mathrm{H}_{2} \mathrm{SO}_{4}$ & $1.28 \pm 0.04$ & 75.09 \\
\hline $0.5 \mathrm{M} \mathrm{NaOH}$ & $1.20 \pm 0.21$ & 64.23
\end{tabular}


Among the 15 isolates, eight were found to be tolerant to $5 \mathrm{mM} \mathrm{Cr}(\mathrm{VI})$ (Table 1), which is common among the isolates obtained from metal contaminated mining areas. Similar metal tolerance was also reported by Ahmad et al. 2005 in Aspergillus sp. and it was suggested that continuous exposure to heavy metals can lead to the development of tolerance in indigenous fungal populations.

The isolates that tolerated up to $5 \mathrm{mM} \mathrm{Cr}(\mathrm{VI})$ were further screened for their ability for $\mathrm{Cr}(\mathrm{VI})$ biosorption. A. fumigatus S101 was found to be a very suitable for biosorption (Table 2) with a metal loading capacity of 1.868 $\pm 0.91 \mathrm{mM} \mathrm{Cr}(\mathrm{VI})$ per g biomass when the initial $\mathrm{Cr}(\mathrm{VI})$ was $0.5 \mathrm{mM}$. This isolate was thus considered as the most efficient strain and selected for further optimization. Similar efficiency of Aspergillus sp. in $\mathrm{Cr}$ (VI) biosorption was also reported by Ghosh et al. (2015) where the biosorption was reported to be nearly $17.58 \mathrm{mg} \mathrm{Cr}(\mathrm{VI})$ per g biomass. Sivakumar (2016) reported biosorption of $\mathrm{Cr}(\mathrm{VI})$ up to $18.1 \mathrm{mg} \mathrm{L}^{-1}$ from tannery effluents by Aspergillus species such as A. niger, followed by Aspergillus flavus, A. fumigatus, Aspergillus nidulans, Aspergillus heteromorphus, Aspergillus foetidus and Aspergillus viridinutans. Similarly, Singh et al. (2016) reported up to $16.1 \mathrm{mg} \mathrm{g}^{-1} \mathrm{Cr}(\mathrm{VI})$ biosorption by $A$. flavus and is suitable for use in pilot plants for removal of $\mathrm{Cr}(\mathrm{VI})$.

Scanning electron microscope analysis and EDX study of the dried fungal biomass both before and after $\mathrm{Cr}(\mathrm{VI})$ biosorption were done and EDX analysis showedthe presence of $\mathrm{Cr}$ bound to the fungal biomass (Fig, 2B). However, no distinct change in biomass morphology was noticed. The biosorbed chromium was assumed to be trivalent in nature, as $\mathrm{Cr}(\mathrm{VI})$ is reduced to insoluble $\mathrm{Cr}(\mathrm{III})$ which can freely bind to these sites. After binding $\mathrm{Cr}$ (III) is also reported to help in further heterogeneous nucleation and crystal growth (Park et al. 2005).

FTIR spectral analysis of the biomass also provided vital information regarding the functional group responsible for $\mathrm{Cr}(\mathrm{VI})$ biosorption. It has been usually found that anionic ligands such as phosphoryl, carbonyl, sulfhydryl and hydroxyl groups contribute greatly to the biosorption processes. Fungi are composed of polysaccharides such as $\beta$-glucan, chitin and chitosan, glycoproteins, lipids, D-galactosamine polymers and polyuronides, which act as sites of metal binding (Vimala, Das 2011). In the present case there was a change in the spectra after $\mathrm{Cr}(\mathrm{VI})$ biosorption by the fungal biomass mainly in the range of 1642 to $1038 \mathrm{~cm}^{-1}$ (Fig. 3A, B), which indicates the presence of $-\mathrm{OH}$ and $-\mathrm{N}-\mathrm{H}$ ionizing groups as the main functional groups playing a vital role in biosorption. Bai and Abraham (2001) and Khambhaty et al. (2009) suggested that $\mathrm{Cr}(\mathrm{VI})$ anions interacted strongly with positively charged amines of the cell wall.

Increased initial metal concentration was found to positively influence the metal loading capacity of the dried biomass (Fig. 4), which indicates the efficiency of the biomass to load higher concentration of metals due to availability of more metal binding sites. Such increase in biosorption potential can also be associated with increase in propelling force of higher $\mathrm{Cr}(\mathrm{VI})$ ion concentration, which was more efficient to overcome the mass transfer resistance of metal ions and subsequently resulting in higher collision between $\mathrm{Cr}(\mathrm{VI})$ ions and biosorbents (Tewari et al. 2005; Ahmad et al. 2005; Aravindhan et al. 2012).

Biosorption isotherms equations are used to study the nature of biosorption and to analyze the interrelationship between the mass of the adsorbed component and the concentration of a metal in wastewater (Mandal, Roy 2016). The present study was in good agreement with both Langmuir and Freundlich isotherms, as evident by the high $R^{2}$ value (Fig. $5 \mathrm{~A}, \mathrm{~B}$ ).

$\mathrm{Cr}(\mathrm{VI})$ biosorption by A. fumigatus S101 biomass (Fig. $5 \mathrm{C})$ was in good agreement with the pseudo-second-order kinetic model as the regression coefficient $\left(R^{2}\right)$ was more close to unity for all the different concentration used. Similar results was also reported by Bose et al. (2011) and Mondal et al. (2017) using Jatropha seed press cake and A. niger, respectively.

Biosorption of $\mathrm{Cr}(\mathrm{VI})$ was largely dependent on the $\mathrm{pH}$ of the solution and in the present case was found to increase at lower $\mathrm{pH}$. Maximum biosorption was observed at $\mathrm{pH}$ 5 (Fig. $6 \mathrm{~A}$ ) and $\mathrm{Cr}(\mathrm{VI})$ biosorption efficiency gradually reduced at both and lower and higher $\mathrm{pH}$. Lower or acidic $\mathrm{pH}$ has been reported to enhance the competition between metal ions and $\mathrm{H}^{+}$for metal binding sites of the fungal cell wall, thereby decreasing metal binding efficiency. A similar increase in removal of $\mathrm{Ni}(\mathrm{II})$ at $\mathrm{pH} 4.5$ to 5.5 was reported by Hasan et al. (2000). Optimum temperature was found to be $30{ }^{\circ} \mathrm{C}$, where metal loading capacity was found to be nearly $1.924 \mathrm{mM} \mathrm{Cr}(\mathrm{VI})$ per $\mathrm{g}$ biomass showing the interaction to be endothermic in nature. In the present study, with increase in temperature $\mathrm{Cr}(\mathrm{VI})$ biosorption ability was reduced. A similar phenomenon was also reported by Pal et al. (2006) and Choudhury et al. (2012), which is characteristic of a chemical reaction or bond being involved in the adsorption process (Mohapatra et al. 2010).

Initial biomass concentration was also found to effect the $\mathrm{Cr}(\mathrm{VI})$ removing ability of the isolate. In the present study, with an increase in biomass concentration from 1 to $3 \%$ the biosorption efficiency decreased (Fig. 7). Ghosh et al. (2015) reported a similar phenomenon with A. niger, where maximum biosorption occurred at $1 \mathrm{~g} \mathrm{~L}^{-1}$ and with increase in biomass the biosorption ability decreased. Similar observations were noted for uptake of $\mathrm{Cr}(\mathrm{VI})$ by Aspergillus (Al-Ashesh, Duvnjak 1995).

Addition of different metal ions along with $\mathrm{Cr}(\mathrm{VI})$ was found to have a profound effect on the biosorption potential. The reduced uptake of $\mathrm{Cr}(\mathrm{VI})$ in presence of metals such as $\mathrm{Ni}(\mathrm{II}), \mathrm{Pb}(\mathrm{II})$ and $\mathrm{Zn}$ (II) (Table 4) was evident in the present study, which may be explained by competition between the metal ions for active sites of the cell wall. The 
biosorption was not inhibited in presence of $\mathrm{Fe}(\mathrm{III})$ and $\mathrm{Cu}(\mathrm{II})$, which may be attributed to the difference in ionic radii of the metal and metal binding site (Sag, Kutsal 1996).

Pretreatment with chemical as well as physical method also affected the biosorption potential. Autoclaving as well as acid and alkali treatment of the biomass reduced the biosorption ability of Aspergillus biomass, which was due to disorganization of metal binding sites (Ghosh et al.2015; Kapoor et al. 1999).

In conclusion, in the present study A. fumigatus (S101) was isolated from the coal mine soils of Jharkhand, India. This strain showed tolerance to $\mathrm{Cr}(\mathrm{VI})$ and is capable of biosorbtion of $\mathrm{Cr}(\mathrm{VI})$ from aqueous solutions under different conditions. The isolate can be further utilized to remove $\mathrm{Cr}(\mathrm{VI})$ from $\mathrm{Cr}(\mathrm{VI})$ contaminated waste water. However, further detailed studies are necessary to assess the economic feasibility of the process.

\section{Acknowledgements}

We would like to acknowledge the Electron Microscopic facilities at Centre for Research in Nanoscience and Nanotechnology, Calcutta University, Kolkata, India for SEM and EDAX analysis and Department of Chemistry, Midnapore College, West Bengal, India for FTIR analysis. We would also like to thank Professor A.K. Paul, Microbiology laboratory, Department of Botany, University of Calcutta, India for his support during this study.

\section{References}

Ahmad I., Zafar S., Aqil F. 2005. Heavy metal biosorption potential of Aspergillus and Rhizopus sp. isolated from wastewater treated soil. J. Appl. Sci. Environ. Manage. 9: 123-126.

Aravindhan R., Fathima A., Selvamurugan M., Rao J.R., Balachandran U.N. 2012. Adsorption, desorption, and kinetic study on $\mathrm{Cr}$ (III) removal from aqueous solution using Bacillus subtilis biomass. Clean. Technol. Environ. Policy 14: 727-735.

Bagchi D., Stohs S.J., Bernard W.O., Bagchi M., Preus H.G. 2002. Cytotoxicity and oxidative mechanism of different forms of chromium. Toxicology 180: 5-22.

Bai R.T., Abraham E. 2001. Biosorption of $\mathrm{Cr}(\mathrm{VI})$ from aqueous solution by Rhizopus nigricans. Bioresour. Technol. 79: 73-81.

Black C.A. 1965. Methods of Soil Analysis. Part 1. American Society of Agrononomy, Madison, Wisconsin, USA.

Bose A., Kavita B., Keharia H. 2011. The suitability of Jatropha seed press cake as a biosorbent for removal of hexavalent chromium from aqueous solutions. Bioremed. J. 15: 218-229.

Cervantes C., Ohtake. H. 1988. Plasmid-determined resistance to chromate in Pseudomonas aeruginosa. FEMS Microbiol. Lett. 56: 173-176.

Chatterjee S., Ghosh I., Mukherjea K.K. 2011. Uptake and removal of toxic Cr(VI) by Pseudomonas aeruginosa: Physico-chemical and biological evaluation. Curr. Sci. 101: 645-652.

Choudhury T.R., Pathan K.M., Amin N., Ali, M., Quraishi S.B. 2012. Adsorption of $\mathrm{Cr}$ (III) from aqueous solution by groundnut shell. J. Sci. Water Resour. 1: 144-150.

Congeevaram S., Dhanarani S., Park J., Dexilin M., Thamaraiselvi K. 2007. Biosorption of chromium and nickel by heavy metal resistant fungal and bacterial isolates. J. Hazard. Mater. 146: 270-277.
Das S.K., Chakrapani G.J. 2011. Assessment of trace metal toxicity in soils of Ranigunj Coalfield, India. Environ. Monit. Assess. 177: 63-71.

Dey S., Paul A.K. 2010. Occurrence and evaluation of chromium reducing bacteria in seepage water from chromite mine quarries of Orissa, India. J. Water Res. Prot. 2: 380-388.

Ghosh S., Mondal A., Paul A.K. 2015. Hexavalent chromium biosorption by dried biomass of Aspergillus niger NUA 101 isolated from Indian ultramafic complex. African J. Microbiol. Res. 9: 220-229.

Gilman J.C. 1957. A Manual of Soil Fungi. The Iowa State College Press, Iowa USA.

Hasan S., Hashim M.A., Gupta B.S. 2000. Adsorption of $\mathrm{NiSO}_{4}$ in Malaysian wood surface. Bioresour. Technol. 72: 153-158.

Ho Y.S., McKay G. 1999. Pseudo-second order for adsorption process. Process Biochem. 34: 451-465.

Jia C., Zhang Y., Wang H., Ou, G. Lui Q., Lin J. 2014. Rapid biosorption and reduction removal of $\mathrm{Cr}(\mathrm{VI})$ from aqueous solution by dried sea weeds. J. Centr. South. Univ. 21: 28012809.

Johnson D.B., McGinness S. 1991. A highly efficient and universal solid medium for growing mesophilic and moderately thermophilic, iron-oxidizing, acidophilic bacteria. J. Microbiol. Meth. 13: 113-122.

Kapoor A., Viraraghavan T., Cullimore D.R. 1999. Removal of heavy metals using fungus Aspergillus niger. Bioresour. Technol. 70: 95-104.

KhambhatyY., Mody K., Basha S., Jha B. 2009. Kinetics, equilibrium and thermodynamic studies on biosorption of hexavalent chromium by dead fungal biomass of marine Aspergillus niger. Chem. Eng. J. 145: 489-495.

Khan M.H.R., Seddique A.A., Rahman A., Shimizu Y. 2017. Heavy metals contamination assessment of water and soils in and around Barapukuria coal mine area, Bangladesh. Am. J. Environ. Prot. 6: 80-86.

Lagergren S. 1898. Zurtheorie der sogenannten adsorption geloster stoffe. Kungliga Vetenskapsakademiens Hardlingar 24: 1-39.

Mahato M.K., Singh P.K., Tiwari A.K. 2014. Evaluation of metals in mine water and assessment of heavy metal pollution index of east bokaro coalfield area, Jharkhand, India. Int. J. Earth Sci. Eng. 7: 1611-1618.

Mala J.G.S., Nair B.U., Puvanakrishnan R. 2006. Accumulation and biosorption of chromium by Aspergillus niger MTCC2594. J. Gen. Appl. Microbiol. 52: 179-186.

Mandal N.K., Roy S. 2016. Optimization study of adsorption parameters for removal of phenol on gastropod shell dust using response surface methodology. Clean Technol. Environ. Policy 18:429-447.

Manna A., Maiti R. 2017. Geochemical contamination in the mine affected soil of Raniganj Coalfield - A river basin scale assessment. Geosci. Front. 9: 1-14.

Masto R.E., Sheik S., Nehru G., Selvi V.A., George J., Ram L.C.. 2015. Assessment of environment soil quality around Sonepur Bazari mine of Raniganj coalfield, India. Solid Earth 6: 811821.

Mohapatra M., Mohapatra L., Singh P., Anand S., Mishra B.K. 2010. A comparative study on $\mathrm{Pb}(\mathrm{II}), \mathrm{Cd}(\mathrm{II}), \mathrm{Cu}(\mathrm{II}), \mathrm{Co}(\mathrm{II})$ adsorption from single and binary aqueous solutions on additive assisted nano-structured goethite. Int. J. Eng. Sci. Technol. 2: 89-103. 
Page A.L., Miller R.H., Keeney D.R. 1982. Methods of Soil Analysis. Part 2. Soil Sci. Soc. Am., Madison, WI.

Park C.H., Keyhan B., Wielinga B., Fendorf S., Matin A. 2000. Purification to homogeneity and characterization of a novel Pseudomonas putida chromate reductase. Appl. Environ. Microbiol. 66: 1788-1795.

Park D., Yun Y.S., Park J.M. 2005. Use of dead fungal biomass for the detoxification of hexavalent chromium: screening and kinetics. Process. Biochem. 40: 2559- 2565.

Rai D., Sass B.M., Moore D.A. 1987. Chromium (III) hydrolysis constants and solubility of chromium (III) hydroxide. Inorg. Chem. 26: 345-349.

Raper K.B., Thom C. 1984. A Manual of the Penicillia. International Books and Periodicals Supply Service, New Delhi, India.

Sag Y., Kutsal T. 1996. Fully competitive biosorption of chromium (VI) and iron(III) ions from binary metal mixtures by $R$. arrhizus: Use of competitive Langmuir model. Proc. Biochem. 31: 573-585.

Singh R., Kumar M., Bishnoi N.R. 2016. Development of biomaterial for chromium(VI) detoxification using Aspergillus flavus system supported with iron. Ecol. Eng. 91: 31-40.

Sivakumar D. 2016. Biosorption of hexavalent chromium in a tannery industry wastewater using fungi species. Glob. J. Environ. Sci. Manage. 2: 105-124.

Srivastava S., Thakur I.S. 2006. Isolation and process parameter optimization of Aspergillus sp. for the removal of chromium from tannery effluent. Bioresour. Technol. 97: 1167-1173.

Subbiah B.V., Asija G.L. 1956. A rapid procedure for estimation of nitrogen in soils. Curr. Sci. 25: 259-260.

Tewari N., Vasudevan P., Guha B.K. 2005. Study on biosorption of Cr(VI) by Mucor hiemalis. Biochem. Eng. J. 23: 185-192

Upadhyay N., Vishwakarma K., Singh J., Mishra M., Kumar V., Rani R., Mishra R.K., Chauhan D.K., Tripathi D.K., Sharma S. 2017. Tolerance and reduction of chromium(VI) by Bacillus sp. MNU16 Isolated from contaminated coal mining soil. Front. Plant Sci. 8: 778.

Zafar S., Aqil F., Ahmad I. 2007. Metal tolerance and biosorption potential of filamentous fungi isolated from metal contaminated agricultural soil. Bioresour. Technol. 98: 25572561. 